\title{
Botanicals as Eco-Friendly Biorational Alternatives of Bio Insecticide against Callosobruchus Maculatus (F.) (Coleoptera: Bruchidae) Stored Pulses - A Review
}

\author{
K. Govindan ${ }^{1 *}$, S. Geethanjali ${ }^{2}$, S. Douressamy ${ }^{1}$, M. Pandiyan $^{3}$ and G. Brundha ${ }^{1}$ \\ ${ }^{1}$ Department of Crop Protection, ${ }^{2}$ Department of Crop Improvement \\ ${ }^{3}$ Department of Plant Breeding and Genetics, Agricultural College and Research Institute, \\ Valavachanur - 606 753, Thiruvannamalai District, Tamil Nadu, India \\ *Corresponding author
}

\section{A B S T R A C T}

The presents review article has been reviewed to know the importance of different plant products (botanicals) against Callosobruchus maculatus (F.) (Coleoptera: Bruchidae) the potential insecticidal botanicals in the management in storage condition and infesting the various stored pulses such as (black gram, greengram, cowpea, Bengal gram, Mmung bean etc). Callosobruchus maculatus is one of the most serious pests brought into storage

\section{Keywords}

Pulse beetle Callosobruchus maculatus - Plant products- eco friendly management

Article Info

Accepted:

18 May 2020

Available Online:

10 June 2020 containers with harvested black gram that can cause total loss of the stored crop in a few months. The estimated post-harvest losses caused by bruchids to the pulses ranged from $30-40 \%$ within six months and when left unattended losses could be up to 100 per cent. Pulse beetles, C. maculatus are the most serious pests in stored legumes in majority of tropical countries. Botanicals have been used since time immemorial for protection of stored products against common pests. They acts as repellents, antifeedants, toxicants and behave as natural grain protectants by behaving as chemosterilants/reproduction inhibitors or insect growth and development inhibitors. Attention has been given to the possible use of plant products or plant dry powders as promising alternatives to synthetic insecticides in controlling insect pests of stored products. Different botanicals and it is formulations have been reported time to time showing pronounced insecticidal activity, repellence to pest, oviposition deterrency, adult emergence inhibition, ovicidal, larvicidal, pupaecidal activity and feeding deterrency based on their contact toxicity and fumigation effects. Botanicals are biodegradable, non-residual, equally effective and easily available botanicals, cost effective and non-toxic to natural enemies. Some botanicals have also been practically proved efficacious to protect the stored food commodities from the bruchids during storage conditions. Hence, they may be recommended in food security programmes as eco-friendly and biorational alternatives of synthetic insecticides providing integrated management of the losses of stored food commodities due to infestation of bruchids.

\section{Introduction}

Pulses are also known as "Poor man's meat, Pulses are an important part of the vegetarian diet of Indian subcontinent, being a rich source of protein $(20-30 \%)$ and high nutritional value, offer the most practical means of solving malnutrition in our country 
(Rupesh et al., 2016). India has achieved first rank in World area (35\%) and production (25\%) under Pulses; India has an area of about 25 million ha of pulses producing 16.5 million tonnes of Pulses. This is $35 \%$ percent of the world area and $25 \%$ of world production (Rupesh et al., 2016). However, the average yield level in India is $650 \mathrm{~kg} / \mathrm{ha}$ against the world average of $909 \mathrm{~kg} / \mathrm{ha}$. In Tamil Nadu, Black gram (46\%) and Green gram $(25 \%)$ are the major Pulse crops accounting for about 71 percent of the area under Pulses and the average yield level is far below the national average. Tamil Nadu, Black gram (46\%) and Green gram $(25 \%)$ are the major Pulse crops accounting for about 71 percent of the area (Vasanthakumar, 2016).

Per capita requirement of Pulses (60 gm for male and $55 \mathrm{gm}$ for female) is less than the availability (42 gm). Globally, India stands first in terms of area and production of Pulses. Black gram is (4.05 lakh ha), Production (3.10 lakh tonnes) and Productivity (851 $\mathrm{kg} / \mathrm{ha}$ ) (Vasanthakumar, 2016). Black gram and green gram account for about 71 per cent of the area in Tamil Nadu (Vasanthakumar, 2016). Black gram Vigna munga (L.), an important legume crop suffers losses both qualitatively and quantitatively due to the attack by bruchids in the post-harvest stages (Raghu et al., 2016).

All the pulses seeds should be stored to meet home consumption as well as for sale. Major constraints for the production and protection of pulses are pest infestation in the field and in storage. Infestation begins in the field but causes serious damage to the seeds during storage (Sanon et al., 2018). Major constraints for the production and protection of pulses are pest infestation in the field and in storage (Manju et al., 2019). Stored product pests are a great challenge in our economy because they infect and contaminate stored agricultural products and animal feed
(Jacobs et al., 2019). Stored products are frequently damaged by insect pests and this may account to $5-10 \%$ in temperate zones and 20-30\% in the tropics (Nakakita, 1998). The post-harvest losses and quality deterioration caused by storage pests are major problems throughout the world. Pulse beetle is the most serious pest in stored legumes in majority of tropical countries (Ratnasekera and Rajapakse, 2012).

Among the insect pests of various pulses crops, pulse beetle, Callosobruchus maculatus (F.) (Coleoptera: Bruchidae) is a cosmopolitan field-to-store pest ranked as the principal post-harvest pest, which lead to a reduction of commercial value and seed germination, in addition the grains become unfit for human consumption (Atwal and Dhaliwal, 2005). Infestation begins in the field but causes serious damage to the seeds during storage (Kayode and Ileke, 2019). Bruchids are known to inflict quantitative and qualitative losses to stored pulses (Soe et al., 2020). Several pulses is seriously infested by pulse beetles $C$. maculatus all over the world (Dimetry et al., 2002; Ahmed, 2010; Hafez et al., 2013).

At present, pest control measures in storage rely on the use of synthetic insecticides and fumigants, which is the quickest and surest method of pest control but it is also not advised to mix the insecticides with food grains. Their indiscriminate use in the storage, however, has led to a number of problems including insect resistance, toxic residues in food grains (Fishwick, 1988), environmental pollution (WMO, 1995) and increasing costs of application. In view of these problems together with the upcoming WTO regulations, there is a need to restrict their use globally and implement safe alternatives of conventional insecticides and fumigants to protect stored grains from insect infestations (Yusof and Ho, 1992; Subramanyam and 
Hagstrum, 1995). Pesticides to control pest outbreaks remains high (Farrar et al., 2016; Vasileiadis et al., 2017).

Many synthetic insecticides have been found effective against stored product pests but proved to be hazardous to men and domestic animals. The over reliance on and nonjudicious use of synthetic pesticides especially insecticides since last four decades led to wide spectrum of pests problem like pests resistance to chemicals, resurgence of pests, residues in food and soil and risks to human and animal health, besides environmental pollution (Mohapatra and Gupta, 1998). Musa and Uddin (2016) reported that many plants possess activities against stored grain pests. To solve this problem, many researchers have discovered alternative pest management products derived from plants (Isman, 2013).

The insecticidal constituents of many plant powders are due to their enrichment of phytochemicals such as alkaloids, tannins, and flavonoids (Afolabi et al., 2018). Plant products are cheap and are easily accessed by farmers and small-scale industries in the form of crude or partially purified extracts. It was indicated that mixing storage pulses and plant products such as leaf, bark, powder or extracted oils reduced the oviposition rate, inhibited the adult emergence of bruchids and decreased the seed damage rate (Onu and Aliyu, 1995; Shaaya et al., 1997; Keita et al., 2001; Tapondjou et al., 2002; Govindan and Nelson, 2007; Ahmed, 2010; Islam et al., 2013; Musa and Adeboye, 2017; Sanon et al., 2018 ; Manju et al., 2019; Soe et al., 2020).

In the storage period, pulse beetles are managed by using synthetic insecticides, vegetable oils, plant powder and inert materials. The use of natural plant products as insecticide is gaining importance in recent years due to ill effects of synthetic insecticides such as pest resistance, pest resurgence, and pest residues in food and pollution. The botanicals are easily biodegradable and ecologically compatible without posing environmental pollution. Hence, many scientists are doing research work on the effect of various plants on pulse beetle and other stored products insects. The research works carried out based botanicals by several scientists works reviewed and presented under the following sub headings.

Losses caused by Callosobruchus maculatus Insecticidal action of botanicals on Callosobruchus maculatus

Effect of botanicals on oviposition, egg hatching and adult emergence of Callosobruchus maculatus and seed weight loss.

\section{Losses caused by Callosobruchus maculatus in pulses}

Pulses are annual and seasonal crops that can be stored for several months. However, these are at high risk of damage due to post harvest losses which can be up to 25-50 per cent ( Lal and Verma, 2007), These losses are linked to insufficient and poor storage facilities, lack of knowledge of advanced technology in post-harvest pulse management and harsh climatic conditions particularly in developing countries like India (Singh and Larson 2016). During storage, pulse beetles or bruchids attack the pulse seeds and Callosobruchus chinensis L. and Callosobruchus maculatus F. are common bruchid species. These bruchids causes about 5-10\% losses during storage (Lal and Verma, 2007). These losses vary widely in different climatic conditions, pulse varieties, geographical locations and processing and storage techniques.

The pulse beetle, $C$. chinensis and $C$. maculatus are the two important species of pulse beetle. The loss caused by the pulse 
beetles has been variable. The loss caused by pulse beetle $C$. chinensis was up to 55.20 per cent in chickpea (Ramsingumrao and Verma, 2003). Sridharan and Venugopal (1994) stated that $C$. maculatus could spoil the quality of black gram seeds by as much as 100 per cent. Feeding by half-mature larvae of $C$. maculatus often lead to most noticeable decline in germination in pulse seeds (Yadava and Bhatnaga, 1987). Singh and Sharma (1982) observed that the damage caused by $C$. maculatus and the loss of germination was significantly higher in green gram than in black gram after five months of storage. Caswell (1973) reported that annual losses of cow pea in Nigeria due to C. maculatus was 2900 tons (dry weight). C. maculatus is one of the most serious pests brought into storage containers with harvested black gram that can cause total loss of the stored crop in a few months (Dongre et al., 1996). The estimated post-harvest losses caused by bruchids to the pulses ranged from 30-40 per cent within 6 months and when left unattended losses could be up to 100 per cent (Dongre et al., 1996; Mahendran and Mohan, 2002).

Callosobruchus spp. can cause damage of legume seeds up to $100 \%$ during storage In Thailand (Gbaye et al., 2011). Gujar and Yadav (1978) recorded 32.2 to 55.7 per cent loss in seed weight and 17.0 to 53.5 per cent loss in protein content. The insect spends its entire immature stage in individual legume seeds, where they cause weight loss, decrease in germination potential increase in moisture, free fatty acid levels, decrease in protein contents.

Insecticidal action of botanicals on callosobruchus maculatus (F.)

Insecticidal action of piper nigrum on C. maculates

Piper nigrum L. seed is well known for its insecticidal properties against Callosobruchus maculatus. Piper nigrum have active compound called Piperine is a major active principle compound found in seeds and it is the responsible for the killing the $C$. maculatus (Swamy and Raja, 2018). Govindan et al., (2010) who found that $P$. nigrum dust formulation (Pn10D) was prepared by mixing pulverized seed powder of P. nigrum (10\%) and fly ash (90) (Pn10D) at 4.00 percent caused cent percent mortality of $C$. maculatus after $72 \mathrm{hr}$ after the treatment. Islam et al., (2013) found that $P$. nigrum $1 \mathrm{~g} / \mathrm{kg}$ gram seeds showed 100.00 per cent mortality to $C$. maculatus. Rajapakse, (1990) observed that $P$. nigrum 2 per cent coated seeds showed cent per cent mortality to $C$. maculatus. Hussain and Rahman, (2008) stated that $P$. nigrum seed powder causes 100 per cent mortality to $C$. maculatus within $24 \mathrm{hrs}$ after treatment. Abdullah et al., (2017) observed black pepper, $P$. nigrum caused highest mortality at $24 \mathrm{hr}(98.3 \%)$ at 48 hur after treatment $(100.0 \%)$ to $C$. maculatus. Chudasama et al., (2015) refer that C. maculatus with 5 per cent black pepper seed extract treated with green gram very effective and controlling the $C$. maculatus. Manju et al., (2019) observed that $P$. nigrum one per cent treated green gram seeds resulted in 100 mortality to $C$. maculatus within $12 \mathrm{~h}$ after treatment. Shah and Mahdi, 2016 observed that $P$. nigrum seed powder highly toxic to $C$. maculatus. Mixing of 1 per cent seed powder of $P$. nigrum resulted in 100 per cent mortality to $C$. maculatus within $12 \mathrm{hr}$ (Manju et al., 2019). Rathod et al., (2019) observed that black pepper powder $3 \mathrm{~g} / \mathrm{kg}$ of green gram seeds results showed cent per cent mortality two days after treatment . Several scientists reported their efficacy of black pepper, $P$. nigrum seed powder and their toxicity to adults of $C$. maculatus. (Govindan and Nelson , 2007; Shukla et al., 2009; Singh 2011; Islam et al., 2013 ; Mahdi et al., 2016; Swamy and Raja, 2018 ; Rathod et al., 2019; Emeasor and Chukwu, 2019). 


\section{Insecticidal action of piper guineense on C. maculatus}

Piper guineense powder $(0.1 \mathrm{~g} / 20 \mathrm{~g})$ admixed with cowpea caused 100 per cent mortality to C. maculatus adult (Ivbijaro and Agbaje, 1986). Extract of $P$. cubeda fruit when applied topically caused 87 per cent mortality of C. maculatus (Su, 1990). Mbata and Ekpendu (1992) reported that $P$. guineense seed powder caused high mortality of $C$. maculatus even at low concentration. Lale (1992) reported that $P$. guineense powder at $1.5 \mathrm{~g} / 20 \mathrm{~g}$ cowpea seeds caused 96 per cent mortality of $C$. maculatus adult when assessed at 48 hours. The insecticidal properties of Piper guineense could be attributed to the presence of piperine (Oparaeke, 2006). Abdullahi and Muhammad (2004) reported that $P$. guiennese at $1 \mathrm{~g}$ per 50 gram cowpea seed caused 100.00 per cent mortality of $C$. maculatus.

\section{Insecticidal action of acorus calamus on $C$.} maculatus

Acorus calamus have high insecticidal activity due to active compound called $\beta$ asarone (cis-2, 4, 5-trimethoxy-1propenylbenzene) is a sesquiterpenoid, is a major active principle found in oil of the rhizomes and it is the responsible for the killing the $C$. maculatus (Shreelaxmi et al., 2017). The rhizomes of $A$. calamus possess antibacterial, bio pesticide and antifungal properties (Rani et al., 2003). Su (1991) reported that topical application of A calamus oil at $30 \mu \mathrm{g}$ per insect caused 98 per cent mortality of $C$. maculatus. The sweet flag powder mixed with red gram seeds at 1.5 and $2.5 \mathrm{~g}$ per $5 \mathrm{~g}$ seeds gave protection up to three generations of C. maculatus (Shivanna et al., 1994). Govindan and Nelson, (2007) stated that Acorus calamus rhizome powder 2 per cent showed 100 per cent mortality to $C$. maculatus two days after treatment. Acorus calamus rhizome acted as a contact or stomach poison, or antifeedant and repellent on the newly emerged adults of $C$. maculatus (Dhivya et al., 2019). Saranya et al., (2019) who concluded that $A$ calamus hexane extract at 0.1 per cent treated cowpea seeds resulted cent per cent mortality to $C$. maculatus after five days after treatment. Rathod et al., (2019) reported that A. calamus rhizome powder $10 \mathrm{~g} / \mathrm{kg}$ of green gram seeds cent per cent mortality to $C$. maculatus . Several scientists tested their efficacy of sweet flag, A. calamus rhizome powder against the adults of C. maculatus (Chanpark et al., 2003; Shukla et al., 2009; Chandel et al., 2018; Shreelaxmi et al., 2019; Dhivya et al., 2019).

\section{Insecticidal action of azadirachta indica on C. maculatus}

The insecticidal properties of Azadirachta indica could be attributed to the presence of azadirachtin (Oparaeke, 2006).Cowpea seeds $20 \mathrm{~g}$ treated with 1-3 g of dry neem (A. indica) seed powder protected the seed from $C$. maculatus for more than 4 months (Ivbijaro, 1983). Sowunmi and Akinnusi (1983) reported that the powdered neem seed kernels mixed with stored cowpea seeds at 1.0 to 2.0 parts per 100 parts of cowpea seeds was effective for eight months. Tanzubil et al., (1987) found that the neem fruit dust at 10 per cent w/w protected cowpea seeds for 4 months from $C$. maculatus.

Tenzubil (1991) reported that the Neemazal W powder (500 ppm) caused 97.8 per cent mortality of $C$. maculatus adults one day after the treatment. Melia azedarach fruit powder was also toxic to $C$. maculatus (Lakwah et al., 1999). Singh et al., (1994) reported that both neem leaves and seed powder mixed with cowpea seeds at 3 per cent (w/w) caused $85-$ 90 per cent mortality of $C$. maculatus. Kumari and Kumar (1998) also observed that neem leaves and seed powder mixed with cowpea 
seeds at 3 per cent w/w caused $85-90$ per cent mortality of $C$. maculatus adults. Neem oil 2 per cent was very effective against $C$. maculatus (Paneru and Sivakoti, 2001). Akunne et al., (2013) who concluded A. indica leaf powder was also toxic to $C$. maculatus. Neem leaf powder protection from pulse beetle infestation in mung bean (Ahmad et al., 2015).

\section{Insecticidal action of others botanicals against $C$. maculatus}

Several researchers tested, documented the various plant species against $C$. maculatus and presented here. Banja and Maboganje (1999) reported that leaves and seed extracts of Jatropha curcas was most effective against C. maculatus. The seed powder of Dennettia tripetala 1 per cent caused 100 per cent mortality of $C$. maculatus with in 72 hours (Umoetok and Okokon, 1999). Eltayeb and Elhag (2000) observed that one per cent crude extract of Rhazya strica leaves showed 82 per cent repellency for $C$. maculatus.

Application of Chenopodium ambroisoides 5.0 per cent extract caused 54 per cent mortality of $C$. maculatus adults (Kehinde et al., 2002). Insecticidal activity of Tephrosia vogelli against $C$. maculatus was reported by Sara (2004). Mollah and Islam (2005) reported that leaf, stem and root of Murraya paniculata extracted in four different solvents viz., petroleum ether, ethyl acetate, acetone and methanol were toxic to $C$. maculatus. Ratnasekera and Rajapakse, (2012) found that extract of A. squamosa was toxic to adults beetles of $C$. maculatus .

Islam et al., (2013) who observed that the black pepper was effective inhibit the oviposition in $C$. macultus. The leaf powder of Ocimum gratissimum was more effective in causing $C$. maculatus mortality (Felicia et al., 2013). Vojoudi et al., (2014) showed that
Mentha pulegium essential oil was more effective against $C$. maculatus. Black pepper powder possesses high anti-ovipositional potential (Upadhyay and Jaiswal, 2007; Ahmed et al., 2011). Kosini and Nukenine (2017) which reported that Gnidia kaussiana leaf powder highest mortality to $C$. macultus. Mojisola et al., (2016) stated that Citrus sinensis was able to achieve 100 per cent mortality $C$. maculatus at the third hour of exposure. Fotso et al., (2018) observed that $H$. welwitschii leaves powder caused highest mortality to $C$. maculatus in stored cowpea. Eugenia aromatica @ 1 g/20 g admixed cow pea seeds and caused 100 per cent mortality with in $24 \mathrm{hrs}$ (Jacobs et al., 2019). Manju et al., (2019) are found that all the twelve botanical powders were significantly effective against $C$. maculatus insect. Antifeedant deterrent effect showed Alium sativum (61.6\%) and Mondora myristica $(64.9 \%)$ to $C$. macultus (Egwunyenga and Ake, 2019).

Edwin and Anigboro (2019) stated that $A$. sativum and $M$. myristica caused a repellency of 50.3 and 49.945 .5 per cent to $C$. maculatus Yusra, (2020) stated that Piper Cubeba seed powder at $4 \mathrm{~g} / \mathrm{kg}$ mung bean seeds caused 100 per cent mortality seven days after exposure to $C$. maculatus. Leaves extract of Hyptis suaveolens, Alstonia boonei, and Tephrosia vogelii were tested and highly toxic to $C$. maculatus (Ehimemen and Salisu, 2020).

Effect of botanicals on oviposition, egg hatching and adult emergence of callosobruchus maculatus (F.) and seed weight losses

\section{Oviposition}

Eltayeb and Elhag (2000) observed that $P$. nigrum reduced the egg laying by $C$. maculatus. Kehinde et al., (2002) reported the 
ovicidal and oviposition deterrent activities of Chenopodium ambroisoides. N. tabacum, $T$. vogelli and Securidaca longepedonculata significantly reduced the number of progeny of C. maculatus (Boeke et al., 2004). Rajapakse and Vantmden (2004) studied the effect of oil of corn, groundnut, sun flower and sesame and found that they significantly reduced oviposition of $C$. maculatus. Leaf powder of Momordica charantia prevented loss of weight of stored cowpea caused by $C$. maculatus (Sara et al., 2004). Rajapakse and Vantmden (2004) reported that powder of $C$. citratus, Cinnamomum camphora and Derris indica reduced egg laying by $C$. maculatus. Sara et al., (2004) observed the with Ocimum basilucum leaf powder suppress the eggs of C. maculatus.

Govindan et al., (2010) who found that $P$. nigrum dust formulation (Pn10D) was prepared by mixing pulverized seed powder of P. nigrum (10\%) and fly ash (90) (Pn10D) at 4.00 percent was most effective in reducing the oviposition of C. maculatus. Singh, (2011) reported that garlic clove powder acted as best ovipositional deterrent against $C$. maculatus in chickpea. Idoko and Adesina (2012) who reported that $P$. guineense caused the mortality of $C$. maculatus adults and eventual suppression of progeny emergence due to contact toxicity of the powder. Oils of Ocimum sanctum at $1.5 \mu \mathrm{l}$ completely inhibited egg laying of $C$. maculatus (Ratnasekera and Rajapakse, 2012). Devi and Devi (2013) reported the reduction in oviposition of $C$. maculatus in gram treated with neem powder. Gupta et al., (2015) who reported the efficacy of neem leaf powder in reducing oviposition against $C$. maculatus on green gram seeds.

Mojisola et al., (2016) Azadirachta indica (neem) leaf extracts were toxic to adult $C$. maculatus and prevented egg hatching. Neem leaf powder (A. indica) applied @
$1.5 \mathrm{mg} / 100 \mathrm{~g}$ seeds of mungbean decreased total progeny by 38 per cent (Ahmad et al., 2015). Gupta et al., (2015) who reported the efficacy of neem leaf powder in reducing oviposition against $C$. maculatus on green gram seeds. Chudasama et al., (2015) refer that aqueous extracts of plants materials, maximum percentage of $(67.19 \%)$ oviposition deterrence was observed in custard apple seed extract. Minimum number of eggs (3.11 eggs/ 5 females) was laid by 5 pairs of $C$. chinensis in sweet flag plant powder (Kaur et al., 2019). Rathod et al., (2019) who found that $O$. canum leaf powder @ 3g / kg of green gram treated seeds results showed less numbers of eggs were laid.

Manju, et al., 2019 stated that Piper nigrum 1 per cent seed powder treated green gram seeds sowed highest percentage of oviposition deterrence $(71.6 \%)$ in $C$. macultus. Sathyaseelan et al., (2008) who observed that Ocimum canum leaf powder at 5 per cent treated green seeds and caused 68.70 per cent mortality to $C$. maculatus. The Eugenia aromatica @ 1 g/20 g admixed cow pea seeds complete inhibit the oviposition in C. macultus (Jacobs et al., 2019). Niranjana and Karunakaran (2019) stated that $A$. indica 10 per cent leaf powder was found to be the very effective reducing the oviposition by $C$. macultus. Ehimemen and Salisu, (2020) who reported that leaves extract of Hyptis suaveolens, Alstonia boonei and Tephrosia vogelii inhibit the egg laying in C. maculatus.

\section{Adult emergence}

Raja et al., (2000) observed that cowpea seeds treated with 0.5 and 1 per cent methanol and aqueous extract of Vitex negundo significantly reduced the number emergence of $\mathrm{F} 1$ adults of C. maculatus. Tapondijou et al., (2002) reported that powdered leaves of 
Chenopodium ambrosiodes inhibited F1 progeny production and adult emergence. Abdullahi and Muhammad (2004) reported that $P$. quineense fruit powder at $1 \mathrm{~g}$ per $50 \mathrm{~g}$ cowpea seed inhibited the oviposition by 26 per cent and adult emergence by 50 per cent in case of C.maculatus. Swella and Mushobozy (2007) who individually reported Annona senegalensis seed powder had high toxic to oviposition and progeny development by protecting cowpea seeds against the $C$. maculatus infestation. Govindan and Nelson (2008) who reported lower adult emergence of $C$. maculatus in seeds treated with sweet flag powder. Piper guineense reduced adult emergence of $C$. maculatus (Emeasor and Chukwu, 2019).

Plant powders causes sterility to male beetle, thus made the females produced non-fertile eggs (Ojianwuna and Umoru, 2010). Govindan et al., (2010) who found that $P$. nigrum dust formulation (Pn10D) seed powder of $P$. nigrum (10\%) and fly ash (90) (Pn10D) at 4.00 percent was most effective in reducing the adult emergence of $C$. maculatus. Neem leaf powder (A. indica) applied @ 1.5mg/100g seeds of mungbean decreased total progeny by 38 per cent (Ahmad et al., 2015). Oils of Ocimum sanctum at $1.5 \mu \mathrm{l}$ completely inhibited adult emergence of $C$. maculatus. (Ratnasekera and Rajapakse, 2012). Rupesh et al., (2016) reported that Neem oil @ $10 \mathrm{ml} / \mathrm{kg}$ of pigenonpea seeds completely inhibited oviposition and adult emergence of $C$. maculatus.

Piper nigrum $2 \mathrm{~g}$ of powder admixed with $20 \mathrm{~g}$ of mung bean seeds resulted complete inhibit the adult beetle emergences of $C$. macultus (Emeasor and Chukwu, (2019); Manju et al., 2019; Rathod et al., 2019). Kaur et al., (2019) who stated that neem leaf powder $5 \mathrm{~g} / 100 \mathrm{~g}$ of pea seed was highly effective and inhibit the adult beetle emergence. Swamy and Raja (2018) stated that mixing of black pepper powder @ 0.1, 0.2 and 0.3 per cent treated seeds of green gram were also found significantly effective as very negligible numbers $(0.33,1.0$ and 8.33 adults respectively) emerged. The Acorus calamus rhizome powder @ 10g/kg of green gram treated seeds results showed that no emergence of C. maculatus (Rathod et al., 2019). Jacobs et al., (2019) who found that Eugeniaaromatica@1 g/20 g admixed cow pea seeds complete inhibit the adult emergence of $C$. macultus. Reduced no adult emergence with $O$. sanctum leaf powder (Ratnasekera and Rajapakse, 2010).

Reduction in the F1 progeny emergence of $C$. maculatus in the Bambara groundnut treated with Ocimum canum powder (Kosini et al., 2015). Chudasama et al., (2015) observed the maximum percentage $(78.45 \%)$ adult emergence reduction was reported in custard apple seed extract. Mahama et al., (2018) reported that significant reduction in the progeny F1 production of $C$. maculatus on seeds treated with Eucalyptus camaldulensis leaf extracts on Bambara groundnut grains.

Saranya et al., (2019) reported that A calamus hexane extract at 0.05, 0.07, 0.09 and 0.1per cent concentrations treated cow pea seeds were no progeny development of $C$. maculatus. Niranjana and Karunakaran (2019) stated that Annona squamosa 10 per cent could be considered as potential plant extracts against $C$. maculatus. Leaves extract of Hyptis suaveolens, Alstonia boonei and Tephrosia vogelii the reduced the number emergence of $\mathrm{F} 1$ adults of $C$. maculatus (Ehimemen and Salisu, 2020).

\section{Seed weight loss}

Aslam et al., (2002) found lower weight loss when chickpea was treated with clove and balck pepper extract. Swella and Mushobozy 
(2007) refer that Black pepper (Piper spp.) powder and coconut oil showed good potential in protecting cowpea seeds against bruchid damage. Govindan et al., (2010) who found that $P$. nigrum dust formulation (Pn10D) seed powder of $P$. nigrum (10\%) and fly ash (90) (Pn10D) at 4.00 percent was most effective against $C$. maculatus and reducing the seed weight loss in stored black gram. Dauda et al., (2012) who stated that Alium sativum oil as grain protectant in cowpea and reduced seed weight loss and up to three monthsof storage. Udo and Harry (2013) reported that groundnut oil protecting cowpea up to six months of storage period. The botanicals as Curcuma longa, Zingiber officinale and $Z$. officinale had effective and reduced the seed weight loss in cowpea (Asawalam and Anaeto 2014).

Poornasundari and Daniel (2015) found black pepper powder at doses of $0.5,1.0,1.5$ and $2.0 \mathrm{~g}$ mixed with $40 \mathrm{~g}$ of green gram as effective and protection up to six months of storage period. Custard apple leaf powder 2 per cent coated with black gram seeds results showed less infestation of pulse beetle (Suthar and Bharpoda, 2016).

Swamy and Raja (2018) stated that mixing of black pepper powder @ 0.1, 0.2 and 0.3 per cent treated seeds of green gram very effective and reducing the seed weight loss. Jumbo, et al., (2018) showed that oil dosage of Clove and Cinnamon proportionately reduced the losses in bean weight caused by C. maculatus

The green gram seed damage due to pulse bruchids was nil in pepper powder @ 0.4 and 0.3 per cent treated seeds (Swamy and Raja, 2018). Rathod et al., (2019) who stated that black pepper powder causes less infestation and least weight loss noticed. Kaur et al., (2019) stated that no seed damage and weight loss was recorded in pea seeds treated with sweet flag powder at $3 \mathrm{~g} / 100 \mathrm{~g}$ and $5 \mathrm{~g} / 100 \mathrm{~g}$ doses. Minimum grain loss was noted with black pepper@1.00 g/kg (Islam et al., 2013). Minimum weight loss percentage was observed in the cowpea seeds treated with custard apple seed extract at 5per cent Chudasama et al., (2015).

Yusuf, et al., (2019) stated that cowpea seeds treated with $A$. indica, $P$. guineense, $C$. citratus, ranging between 1.88 and 2.09 per cent seed weight loss Niranjana and Karunakaran (2019) stated that A. indica 10 per cent leaf powder was reducing the seed weight loss in black gram. Saranya et al., (2019) stated that $A$. calamus hexane extract at $0.05,0.07,0.09$ and 0.1 per cent concentrations treated cow pea seeds were no seeds weight loss recorded. Leaves extract of Hyptis suaveolens, Alstonia boonei and Tephrosia vogelii tested against $C$. maculatus and protect the stored cowpea seeds from its infestation (Ehimemen and Salisu, 2020).

After reviewing findings of several researchers it can be concluded that piper nigrm , Piper guineense Acorus calamus, Azadirachta indica and other many plants have insecticidal properties had very effective against Callosobruchus maculatus viz., insecticidal action (mortality), oviposition, adult emergence and seed weight loss. Insecticidal toxicity of plant and their alkaloids responsible and found be toxic pulse beetle $C$. maculataus.

Many authors have evaluated the insecticidal (grain protectant) properties of plant products on various species of stored product insect pests. The results clearly show that it is possible to develop methods for grain protectants with reduced use of synthetic chemical insecticides.

The main advantages of botanical pesticides are ecofriendly, easily biodegradable, nontoxic to non-target organisms, and many 
plant-derived natural products acting against insects could be produced from locally available raw materials. They have been numerous botanical pesticides studied at the laboratory level. Therefore, the resource poor farmers can use botanicals controlling pulse beetle is stored black gram as they may not afford to buy chemical pesticides due to high cost. Furthermore, the use of botanical pesticides to control pulse beetle is an appropriate strategy to avoid environmental pollution and other hazards, since the chemical pesticides are used by farmers and in agro industries currently. The insecticides of plant origin could be exploited for the development of novel molecules with highly precise targets for sustainable insect pest management in stored grain.

\section{Acknowledgements}

This review article contains information gathered from numerous published resources, and thus we would like to extend our appreciation to all authors of the references used in this manuscript.

\section{References}

Abdullah, A., Magdi, A.A.M and Ahmed, A.Z. 2017. Efficacy of some botanical oils against stored-product pest cowpea beetle, Callosobruchus maculatus (F.) (Coleoptera: Bruchidae). Int. J. of Zoology Studies, 2(1): 05-09.

Abdullahi, Y.M. and S. Muhamma, 2004. Assessment of the toxic potentials of some plants powders on survival and development of Callosobruchus maculatus. African J. Biotech., 3 (1): 60-62.

Afolabi, O. J., Simon-Oke, I. Adepeju, E. O. and Oniya, M. O. 2018. Adulticidal and repellent activities of some botanical oils against malaria mosquito Anopheles gambiae (Diptera: Culicidae). Beni-Suef University J. of Basic and Applied Sci, 7: 134-138.

Ahmad, K., Adnan, M.Anwar, Hussain, Z. Junaid,
K Saleem, N. 2015. Bioactive neem leaf powder enhances the shelf life of stored mungbean grains and extends protection from pulse beetle. Pakistan J. of Weed Sci. and Res, 21:71-81.

Ahmed, M. E. 2010. Fumigant toxicity of seven essential oils against the cowpea weevil, Callosobruchus maculatus (F.) and the rice weevil, Sitophilus oryzae (L.). Egyptian Academic Journal of Biological Sciences, 2(1): 1-6.

Ahmed, Z., Aslam, M., Naz, F. and Illyas, M. 2011. Bioefficacy of some plant extracts against chickpea beetle, Callosobruchus chinensis L. (Coleoptera: Bruchidae) attacking chickpea. Pakistan J. Zool, 43(4): 733-737.

Akunne, C.E, Ononye, B.U and Mogbo, T.C. Evaluation of the efficacy of mixed leaf powders of Vernonia amygdalina (L.) and Azadirachta indica (A. Juss) against Callosobruchus maculatus (F.) (Coleoptera: Bruchidae). Adv Biosci Bioeng, 1(2):86 95.

Asawalam, E.F and Anaeto, C.G.2014.Laboratory evaluation of five botanicals as protectants against cowpea bruchid Callosobruchus maculatus F. (Coleoptera: Bruchidae) on stored cowpea. Net journals Advancement in Medicinal Plants Res, 2(2): 41-46.

Aslam, M., Khalid. Alikhan and M,Z,H, Bajwa. 2002. Potency of some spices against maculatus (F.) Callosobruchus chinensis (Linnaeus). J. Biological Sci, 2(7): 449-452.

Atwal, A.S. and Dhaliwal, G.S. 2005. Agricultural pests of South Asia and their management. 5th edition. Kalyani Publishers, New Delhi. 390pp.

Banjo, A.D and Maboganje, B. 1999. Relative efficacy of some plant parts and seeds in the control of Callosobruchus maculatus (F.) a pest cow pea [Vigna unguiculata (L.) Walps.] Crop Res. Hisar., 17 (3): 395-398.

Boeke S. J., Baumgart, I. R Van Loon, J. J. A. Van Huis, A. Dicke, M. and. Kossou, D. K 2004. Toxicity and repellence of African plants traditionally used for the protection of stored cowpea against Callosobruchus maculatus , J.Stored Prod. Res., 40 (4) : 423-438 
Caswell, G.H. 1973. The impact of infestation on commodities. Tropical Stored Product Infestation, 25: 19.

Chan Park., Soon Kim, Young-Joon and Ahn. 2003. Insecticidal activity of asarones identified in Acorus gramineus rhizome against three coleopteran stored-product insects. J. Stored Prod. Res, 39 (3): 332342.

Chandel, B.S., Indrani, D and Atul, T. 2018. Screening of plant extract for insecticidal biopotency against Callosobruchus chinensis L. (Coleoptera:Bruchidae) on chickpea, Cicer aritenum L. Int. J. Entomology Res, 3(1): 101-106

Chudasama, J .A, Sagarka, N. B. Sharma, S. 2015. Deterrent effect of plantextracts against Callosobruchus maculatus on stored cowpea in Saurashtra (Gujarat, India). J. of Applied and Natural Sci, 7(1): 187-191.

Dauda, Z., Maina, Y.T. and Richard, B.I. 2012. Insecticidal activity of Garlic (Alium sativum L.) oil on Callosobruchusmaculatus (F.) in postharvest cowpea (Vigna unguiculata (L) Walo. J Bio. Agriculture and Health Care. 2(3): 29-35.

Devi, B.M and Devi, V.N. 2013. Effect of some botanicals on adult mortality, oviposition and development of pulse beetle, Callosobruchus maculatus, F. on gram. Indian J. Ento, 75:295-297.

Dhivya, V., Nelson, S. J. Subramanian, K.S. Edward, Y.S.J.T. Rajamani, K. Santhanakrishnan V.P and Sithanantham, S. 2019. Development of Acorus calamus L nanoemulsion and their insecticidal activity against pulse beetle (Callosobruchus maculatus F.), Int. J. of Agriculture Sci., 11(9): 8387-8390.

Dimetry, N. Z., Hafez, M. and Abbass, M. H. 2002. Efficiency of some oils and neem formulations against the cowpea beetle, Callosobruchus maculates (F.) (Coleoptera: Bruchidae). In: Biopesticide and Pest Management, Koul, O., G. S. Dhaliwal, S.S. Marwaha and J.K. Arora (Eds.). 2, 1 10. International Campus Books, New Delhi.

Dongre, T. K., Pawar, S. E. Thakare, R. G and
Harwalkar, M. R. 1996. Identification of resistant sources to cowpea weevil (Callosobruchus maculates (F.) in Vigna sp. and inheritance of their resistance in black gram (Vigna mungo var. mungo). J. of Stored Products Res, 32(3): 201-204.

Edwin, E and Anigboro O. F. 2019. Evaluation of

Repellent Potential of Some Botanical Products against Cowpea Weevil, Callosobruchus maculatus (Fabricius) (Coleoptera: Bruchidae, Jordan J. of Biological Sci, 12(3): 267-273.

Egwunyenga O.A and Ake, J.E. 2019. Antifeedant Potential of Some Aromatic Plants Against Cowpea Weevil, Callosobruchus Maculatus (F.) World J.Agriculture and Soil Sci,1(5): 2-4.

Ehimemen H.E and Salisu N. 2020. Bio-efficacy of Some Plants Ethanolic Extracts Against Cowpea Weevil (Callosobruchus maculatus Fabricius) Infestation of Stored Cowpea Seeds, Asian J. Biotech, 12 (1): 16-21.

Eltayeb, A and Elhag, 2000. Deterrent effect of some botanical products on oviposition of the cow pea brucihid Callosobruchus maculatus (F.) (Coleoptera: Bruchidae). Int. $J$ of Pest manag, 46(2) : 109.

Emeasor, K.C and Chukwu, LA. . 2019. Evaluation of Toxicity of Some Plant Materials Against the Bruchid (Callosobruchus maculatus (F.) (Coleoptera: Chrysomelidae) on Mung Bean (Vigna radiata (L.) Wilczek), Seeds in Storage. Acta Scientific Agriculture, 3(9): 1-5.

Farrar , J. J., Baur, M.E and Elliott, S.F .2016. Measuring IPM impacts in California and Arizona. J. Integr. Pest .Manag .7(1):13.

Felicia, N., Ekeh, I.E.O, Chinedu, I.A. Njoku, I and Joseph E.E. 2013. Effectiveness of botanical powders against Callosobruchus maculatus (Coleoptera: Bruchidae) in some stored leguminous grains under laboratory conditions. African J. Biotech, 12(12):1384-1391.

Fishwick, F. B. 1988. Pesticide residues in grain arising from post-harvest treatments. Aspects of Applied Biol., 17: 37-46.

Fotso, T. G., Nukenine, E. N.. Tchameni, R. Goudoungou, J. W. Kosini, D. Tigamba, V and Adler, C. 2018. Use of Cameroonian 
Hemizygia welwitschii Rolfe Ashby (Lamiaceae) leaf powder against Callosobruchus maculatus and Sitophilus zeamais. J. Entomol. Zool. Stud. 6: 12611269.

Gbaye, O.A., Millard, J.C and Holloway ,G.J. 2011. Legume type and temperature effects on the toxicity of insecticide to the genus Callosobruchus (Coleoptera: Bruchidae). J Stored Product Res, 47:8-12.

Govindan K, Nelson, S. J. 2007. Effect of Piper nigrum seed powder anddust formulation on Callosobruchus maculatus (F.). Annals of Plant Protect. Sci, 15(1): 39-42.

Govindan, K. and S. J. Nelson. Insecticidal action of Acorus calamus rhizome powder and its dust formulations on Callosobruchus maculatus (F.) (Coleoptera: Bruchidae). J. Plt. Prot. Environ. 4(1): 64-69.

Govindann K and Nelson, S.J. 2008. Effect of mixtures of plant powder against pulse beetle, Callosobruchus maculatus (F.) (Coleoptera: Bruchidae). J. of Plant Protect. and Environment., 5:52-57.

Govindan, K., Nelson, S.J and David, P.M.M. 2020. Fly ash - excellent filler for black pepper, Piper nigrum dust formulation against Callosobruchus maculatus (F.), $J$. biopest, 3(1): 320-324.

Gupta, S., Apte S.D and Wast, N. 2015. Efficacy of some plant material on green gram (Vigna radiata L. Wilczek) seed against Callosobruchus maculats (Fab.). European J.Applied Sci, 7:21-24.

Hafez, M., Dimetry, N. Z. and Abbass, M. H. 2013. Insecticidal qnd Biological Efficacy of Two Vegetable Oils Against Callosobruchus maculatus (Fabricius) (Coleoptera: Bruchidae), ), under laboratory conditions. Archives of Phytopathology and Plant Protect. 47(16), 1942-1955.

Hussain, S. A.M and Rahman, K. 2008. Insecticidal effect of some spices on Callosobruchus maculatus (Fabricius) in black gram seeds. Univ. J. Zool. Rajshahi Univ, 27 : 47-50.

Idoko, J.E and Adesina, J.M. 2012. Infestation level of Callosobruchus maculatus of cowpea using different particle sizes of Eugenia aromatic and Piper guineense powders. World J.Engineers and Pure and
Applied Sci, 2(5): 156-162

Islam,S., Haque, A. Ahmed, S Mondal and Dash. C.K. 2013. Evaluation of Some Spices Powder as Grain Protectant Against Pulse Beetle, Callosobruchus Chinensis (L.), Universal J. Plant Sci., 1(4): 132-136, 2013.

Ivbijaro, M. F and Agbaje, M. 1986. Insecticidal activities of Piper guineense Schum and Thonn on the control of Callosobruchus maculatus, Insect Sci. Appl., 1(4): 521-524.

Ivbijaro, M.F. 1983. Preservation of cowpea, Vigna unguiculata (L.) Walps., with neem seed, (Azadirachta indica A. Juss ). Protection Ecology, 5 (2): 177-182.

Ivbijaro, M.F.and M. Agbaje, 1986. Insecticidal activities of Piper quineense Schum, Thonn and Capsicum species on the cowpea bruchid Callosobruchus maculatus (F.). Insect Sci. Appl., 7 (4): 521-524.

Jacobs, M. A, Kayode, D and Yallappa, R. 2019. Eugenia aromatica O. Berg and Afromomum melegueta $\mathrm{K}$. Schum botanical entomocides as possible synergetic protectant against Callosobruchus maculatus (Fabricus) (Coleoptera: Chrysomelidae) infestation on stored cowpea (Vigna unguiculata (L.) Walp.), Herba Pol, 65(2): 1-13.

Jumbo, L.O.V., Haddi, K. Faroni, L.R.D. Heleno, F.F. Pinto F.G and Oliveira E.E. 2018. Toxicity to, oviposition and population growth impairments of Callosobruchus maculatus exposed to clove and cinnamon essential oils. PLOS ONE J., 13(11): e0207618.

Kaur, K.D., Verma, S. C and Sharma, P.L. 2019. Efficacy of plant powders against pulse beetle, Callosobruchus maculatus, L. infesting pea seed, J. Entomol. Zool. Stud, 7(1): 737-741.

Kayode, D. and Ileke, 2019. Insecticidal toxicity of two bruchid-resistant cowpea cultivar powders as cowpea seed protectants against Callosobruchus maculatus (Fab.) (Coleoptera: Chrysomelidae), Food Quality and Safety, 2019, 3, 35-39

Kehinde, A., Kamabonta and Francis Okogbue. 2002. Chenopodium ambroisoides (Chenopodiaceae) as grain protectant for 
the control of the cowpea pest Callosobruchus maculatus (Coleoptera: Bruchidae). J. Fruit and ornamental Res, $165-171$.

Keita, S. M., Vincent, C., Schumit, J. P. Arnason, J. T and Belanger, A. 2001. Efficacy of essential oil of Ocimum basilicum L. and $O$. gratissimum $\mathrm{L}$. applied as an insecticidal fumigant and powder to control Callosobruchus maculatus (Fab.) (Coleoptera: Bruchidae). J. Stored Products Res, 37(4): 339-349.

Kosini, D and Nukenine, E. N. 2017. Bioactivity of novel botanical insecticide from Gnidia kaussiana (Thymeleaceae) against Callosobruchus maculatus (Coleoptera: Chrysomelidae) in stored Vigna subterranean (Fabaceae) grains. J. Insect Sci. 17: 31; 1-7.

Kosini, D., Nukenine, E. N and Tofel, K. H. 2015. Efficacy of Cameroonian Ocimum canum Sims (Lamiaceae) leaf extract fractions against Callosobruchus maculatus (F.) (Coleoptera: Chrysomelidae), infesting Bambara groundnut. J. Entomol. Zool. Stud. 3: 487-494.

Kumari, P and Kumar, D. 1998. Effect of mixture of tobacco leaves and neem seed powder on Callosobruchus chinensis (Linn.) infesting pulse grains. J. Ecotoxicology and Enviromenetal Monitoring. 8(4): 229-232.

Lakwah, F.A.,.Mohamed, R.A Shams E.I and Dien, A.M. 1999. Effect of china berry tree (Melia azedarach) fruits against the cowpea beetle (Callosobruchus maculatus F.), Annals Agric. Sci., 32 (4) : 2149 2158.

Lal, R.R and Verma, P. 2007. Post-harvest management of pulses. Technical bulletin Indian Institute of Pulses Research Kanpur 208: 024

Lale. N.E.S. 1992. Oviposition deterrent and repellent effects of products from dry chilli pepper fruits. Capsicum species on Callosobruchus maculatus(F.) Post Harvest Biology and Tech, 1 (4): 343-348

Mahama, A., Saidou C. Tofel, H. K. Ali, A. Adji, M. B and Nukenine. E. N. 2018. Efficacy of Eucalyptus camaldulensis leaf extracts against the pea beetle Callosobruchus maculatus (F.) and their impact on biochemical and microbiological properties of the treated Bambara groundnut grains. J. Entomol. Zool. Stud. 6: 869-877.

Mahendran, K and Mohan, S. 2002. Technology adoption, estimation of loss and farmers behavior in pulse storage. A study in Western Tamil Nadu. Pestology, 26, 35-38.

Manju, K. Jayaraj, J and Shanthi, M. 2019. Efficacy of botanicals against pulse beetle Callosobruchus maculatus (F.) in green gram. Indian J. Ento, 81(1): 144-147.

Mbata. G.N. and O.T. Ekpendu. 1992. The insecticidal action of four botanicals against three storage beetles Medelingen Vande Facullieit Land Bouwwetenschappen, 57(3): 723-733.

Mohapatra, G.K. and Gupta. G.P. 1998. Pesticide induced resurgence. Pestology, 22 (12): 1420.

Mojisola, E.O., Charles, O.O, Adegoke, E.A Kayode, O.K and Tosin, O.A 2016. Efficacy of Some Plant Extracts as Storage Protectants against Callosobruchus maculatus, J. Biotech. and Biomaterials, $6(1): 1-4$.

Mollah, J.U and Islam, W. 2005. Effect of Murraya paniculata (L.) Jack Extract on the adult mortality of Callosobruchus maculatus F. (Coleoptera: Bruchidae) Frontiers in Natural Product Chemistry, 1 : 25.

Mollah, J.U and Islam, W. 2005. Effect of Murraya paniculata (L.) Jack Extract on the adult mortality of Callosobruchus maculatus F. (Coleoptera: Bruchidae) Frontiers in Natural Product Chemistry, 1 : 25

Musa, A.K. and Uddin, R.O. 2016. Insecticidal Potential of indigenous plant powders against beetle, Callosobruchus maculatus (F.)(Coleoptera: Chrysomelidae) in stored cowpea. Int. J. Phytofuels and Allied Sci, 5(1): 1-14.

Nakakita, H. 1998. Stored rice and stored product insects. In: Rice Inspection Technology Manual. A.C.E. Corporation, Tokyo, Japan, 49-65.

Niranjana, R. F and Karunakaran, S. 2019. Evaluation of botanical extracts against Callosobruchus maculatus F. (Coleoptera: 
chrysomelidae) on different host grains, $J S c$ EUSL , 10 (1) 1-14.

Ojianwuna, C and Umoru, P.A. 2010. Effects of Cymbopogon citratus (lemon grass) and Ocimum suave (wild basil) applied as mixed and individual powders on the eggs laid and emergence of adult Callosobruchus maculatus (F.) (cowpea bruchids). African J. Agricultural Res, 5(20): 2837-2840.

Onu, I. and M. Aliya. 1995. Evaluation of powdered fruits of four pepper (Capsicum spp) for the control of Callosobruchus maculatus (F.) on stored cowpea seed. Int. J. Pest Manage, 41(3): 143-145.

Oparaeke, A.M., 2006. Field evaluation of extracts of five Nigerian spices for control of post-flowering insect pests of cowpea, Vigna unguiculata (L.) Walp. Plant Protect. Sci, 41(1): 14-20.

Paneru, B and Shivakoti, G. P. 2001. Use of Botanicals for the Management of Pulse Beetle (Callosobruchus maculatus F.) in Lentil, Nepal Agricultural Res. Journal.

Raghu, B., Kumar, R .P, Gowda, B, Manjunatha, N, Alur, R. S. 2016. Post harvest seed quality of greengram as influenced by preharvest spray of insecticides. Indian $J$. Agricultural Res. 50(2): 113-116.

Poornasundari, B and Daniel, T. 2015. Pest control in greengram seeds (Vigna radiata) by using plant extracts. Int. letters of natural sci, 40: 38-40.

Rajapakse, R and Vantmden, 2004. Potential of four vegetable oil and ten botanicals powder for reducing H.F. infestation of cowpea by Callosobruchus maculatus (F.), Callosobruchus chinensis and Callosobruchus rhodeianus. J. Stored Prod. Res.,40 (4): 423-428.

Rajapakse, R.H.S. 1990. Effect of five botanicals as protectants of green gram against the pulse beetle Callosobruchus maculatus In: Bruchids and Legumes: Economics, Ecology and Coevolution,. Fujii K., ed. 8590. Kluwer Academic Publishers, The Netherlands.

Raja, N., Albert, S. Ignacimuthu, S. Ofuya, T.I and Dorn, S. 2000. Role of botanical protectants and larval parasotoid Dinarmus vagabundus (Timberlake) (Hymenoptera: Pteromalidae) against C. maculatus (Fab.)
(Coleoptera: Bruchidae) infesting cowpea seeds. Malaysian Applied Biology, 29 (1):255-260.

Ramsingumrao and.Verma, R.A. 2003. Studies on protein composition of different varieties reference of Callosobruchus chinensis L. Indian.J.Ent. 65 (3): 311-314.

Rani, A. S., Satyakala, M. Devi, V. S and Murty, U. S, 2003. Evaluation of antibacterial activity from rhizome extract of Acorus calamus Linn. J. Sci. Ind. Res, 62: 623-625.

Rathod, L., Sasane, A. R. Kawre, P.R Chaware, G.G and Rathod, P.K. 2019. Effect of botanicals on pulse beetle and per cent seed germination of stored green gram, $J$. Pharmacognosy and Phytochemistry, 8(3): 2428-2430.

Ratnasekera, D and Rajapakse, R. 2012. The potential use of indigenous plant materials against Callosobruchus chinensis L. and Callosobruchus maculatus (F.) (Coleoptera, Bruchidae) in stored legumes in Sri Lanka, J. Biopest, 5 (Supplementary): 88-94.

Ratnasekera, D and Rajapakse, R. 2010. Repellent properties of plant oil vapours on pulse beetle (Callasobruchus maculatus (F.) (Coleoptera: Bruchidae) in stored green gram (Vigna radiata L.). Tropical Agrl.Res. and Extension, 12(1): 26- 31.

Rupesh, S., Renu, D. Sunita, Y. Ramesh, S. Umesh, S. Ashok Kumar and Poonam G. 2016. Effect of some botanicals against pulse beetle, Callosobruchus maculatus (F.) infesting pigeonpea, Legume Research, 39 (6): 1043-1047.

Sanon, A., Zakaria, I. Clémentine , D. Niango, B. , Roger M. N and Honora, C. 2018. Potential of Botanicals to Control Callosobruchus maculatus (Col.: Chrysomelidae, Bruchinae), a Major Pest of Stored Cowpeas in Burkina Faso: A Review. Int. J. Insect Sci. 10: 1-8.

Sara, J.B., Barnaud, C. J.A. Joop, V.L. Dansou K. K. Arnold, V.H and Marcel, D. 2004. Efficacy of plant extracts against the cowpea beetle, Callosobruchus maculatus (F) Int. J . Pest manag, 50 (4) : $251-258$.

Saranya, M., Nelson, S.J. Paramasivam M. and Mahalingam C.A. 2019. Evaluation of different solvent extracts of sweet flag 
rhizome, Acorus calamus(L.) on pulse beetle, Callosobruchus maculatus (F.), Indian J. Agric. Res., 53(4) 2019: 373-382

Sathyaseelan ,V., Mohan, S and Baskaran, V. 2008. Efficacy of Some Indigenous Pesticidal Plants Against Pulse Beetle, Callosobruchus chinensis (L.) On Green Gram. J. Entomology, 5(2):128-132.

Shaaya, E., Kostsukorski, M. Eirberg, J and Sukprakarn, C. 1997. Plant oils as fumigants and contact insecticide for the control of stored product insects. J. Stored Products Res, 33(1) : 7-15.

Shah, $\mathrm{H} \quad$ and Mahdi A. 2016. Ovicidal and repellent effects of some spice powders against the Callosobruchus chinensis L. and Callosobruchus maculatus (F.), Bangladesh J. Zool. 44(1): 51-59.

Shivanna, S., Lingappa, S and Patil, B. 1994. Effectiveness of selected plant materials as protectants against pulse beetle, Callosobruchus chinensis (Linn.) during storage of red gram. Karnataka J. Agrl Sci, 7

285-290.

Shreelaxmi, H.. Sharana gouda, Ramachandra, C.T. Roopa, R.S. and Hanchinal, S.G. 2017. Supercritical Fluid Extraction of Oil from Sweet Flag Rhizome (Acorus calamus L.) and Its Insecticidal Activity on Pulse Beetles, (Callosobruchus maculatus, F.), Int.J.Curr.Microbiol.App.Sci , 6(10): 36083615.

Shukla, R., Kumar, A. Prasad, C.S. Srivastava, B and Dubey, N.K. 2009. Efficacy of Acorus calamus $\mathrm{L}$. leaves and rhizome on mortality and reproduction of Callosobruchus chinensis L. (Coleoptera: Bruchidae). Applied Ento. and Zool, 44:241-247.

Singh, C.B and Ron Larson, V.P 2016. Advanced Pulse Storage and Management in Pulse handbook. CommmodityIndia.com.

Singh, O.P and Sharma, S.S. 1982. Studies on grain damage and germination loss caused by Callosobruchus maculatus Fab. in different varieties of moong and mash during storage. Bull. Grain Tech., 20: 20 24.

Singh, R. 2011. Evaluation of some plant products for their oviposition deterrent properties against the Callosobruchus maculatus (F.) on chick pea seeds. J. Agrl. Tech, 7(5): 1363-1367.

Singh, S.C., N.K. Pandey and A. Kumar. 1994. Effect of neem saw dust on mortality of the pulse beetle Callosobruchus chinensis (L.) on black gram (Vigna mungo) J. Ecotoxicol. Environ. Monit., 6 (1): 69-71.

Soe, T.N. Aran, N and Wisut, S. 2020. Bioactivity of some plant essential oils for seed treatment against pulse beetle, Callosobruchus maculatus (F.) (Coleoptera: Bruchidae) on mung bean, Bulgarian J. of Agricultural Sci. 26 (1) 141-147.

Sowunmi, O.E and. Akinnusi, O.A. 1983. Studies on the use of neem seed kernel in the control of stored cowpea beetles Callosobruchus maculatus (F.). Tropical grain Legume Bulletin, 27: 28 - 31.

Sridharan, S and Venugopal, M.S. 1994. Palmarosa for insect control. TNAU Newsl., 21: 1-2.

$\mathrm{Su}$, H.C.F. 1990. Biological activities of hexane extract of Piper cubeba against rice weevils and cowpea weevils (Coleoptera: Curculionidae). J. Entomological Sci, 25 (1): 16-20.

Subramanyam, B and Hagstrum, D.W. 1995. Integrated management of insects in stored products. Marcel Dekker Inc., New York. pp. 426.

Suthar, M. D and Bharpoda, T. M. 2016. Evaluation of botanicals against Callosobruchus chinensis Linnaeus in black gram under storage condition. Indian $J$. Agricultural Res, 50(2): 167-171.

Swamy, S.G and Raja S.V.S.D. 2018. Use of black pepper and clove against pulse beetle Callosobruchus maculatus (F.) in green gram, Indian J. Ento, 80(4): 1291-1295.

Swella, G.B and Mushobozy, D.M.K. 2007. Evaluation of the efficacy of Protectants against Cowpea Bruchids Callosobruchus maculatus (F.) on Cowpea Seeds Vigna unguiculata (L.) Walp . Plant Protect. Sci., 43(2): 68-72.

Swella, G.B and Mushobozy, D.M.K. 2007. Evaluation of the efficacy of Protectants against Cowpea Bruchids, Callosobruchus maculatus (F.) on Cowpea Seeds Vigna unguiculata (L.) Walp. Plant Protect. Sci, 43(2): 68-72. 
Tanzubil, P.B. 1991. Control of some insect pests of cowpea (Vigna unguiculata) with neem (Azadirachta indica A.Juss.) in Northern Ghana. Tropical Pest Management, 37, 216 $-217$.

Tanzubil, P.B., Schmutterer, $\mathrm{R}$ and Ascher. K.R.S. 1987. The use of neem products in controlling the cowpea weevil, Callosobruchus maculatus (F.) (Azadirachta indica A. Juss) and other tropical plant. In: Proceedings of the $3 \mathrm{rd}$ International Neem Conference, Nairobi, Kenya. 517-523.

Tapondjou, L. A., Adler, C. Bouda, H and Fontem, D. A. 2002. Efficacy of powder and essential oil from Chenopodium ambrosiodes leaves as post-harvest grain protectants against six-stored products beetles. J. Stored Products Res, 38(4): 395402.

Udo, I.O and Harry, G. I. 2013. Effect of groundnut oil in protecting stored cowpea, Vigna unguiculata from attack by cowpea Callosobruchus maculatus (F.). J. Bio. Agriculture and Health Care. 3 (1): 89-92.

Umoetok, S.P.A and Okokon. F.A. 1999. Evaluation of powder of Deenettia tripatala seeds and pirimiphos - methyl for the control Callosobruchus maculatus (F.) on stored cowpea. Global J. Pure and Applied Sci, 5 (4): 437- 439.

Vasanthakumar, J. 2016. Constraints to Productivity of Black Gram (Vigna mungo L.) and Green Gram (Vigna radiata L.) in Tamil Nadu, Indian J. Natural Sci. 7(38): 16-21.

Vasileiadis, V.P, Dachbrodt-S.S. Kudsk, P,
Colnenne D.C. Leprince , F. Holb I.J, Kierzek, R. Furlan, L. Loddo, D. Melander, B. Jorgensen, L.N. Newton, A.C. Toque, C. Van Dijk, W. Lefebvre, M. Benezit, $\mathrm{M}$ and Sattin, M. 2017. Sustainability of European winter wheat- and maize-based cropping systems: economic, environmental and social ex-post assessment of conventional and IPM-based systems. Crop Prot , 97:60.

Vojoudi, S., Esmaili, M. Farrokhi, M and Saber, M. 2014. Acute toxicity of kaolin and essential oils from Mentha pulegium and Zingiber officinale against different stages of Callosobruchus maculatus under laboratory conditions. Archives of Phytopathology and Plant Protection, 47(3): 285-291.

WMO, 1995. Scientific assessment of ozone depletion: World meteorological Organization global ozone research and monitoring project. Report No. 37, WMO, Geneva, Switzerland.

Yadava, S.R.S and Bhatnagar. K.N.1987. A preliminary study on the protection of stored cowpea grains against pulse beetle, by indigenous plant products. Pesticides. 21 (8): 25-29

Yusof, O and Ho, S. H.1992. A survey of insecticidal resistance in Sitophilus zeamais Motsch. in Malaysia and Singapore. $J$. Plant Protec. in the Tropics, 9: 219-225.

Yusra J. T. 2020. Efficacy of three botanical powders as mung bean grain protectants against Callosobruchus maculatus (Fabricius) (Coleoptera:Bruchidae), Plant Archives, 20 (1): 971-977.

\section{How to cite this article:}

Govindan. K., S. Geethanjali, S. Douressamy, M. Pandiyan and Brundha. G. 2020. Botanicals as Eco-Friendly Biorational Alternatives of Bio Insecticide against Callosobruchus maculatus (F.) (Coleoptera: Bruchidae) Stored Pulses - A Review. Int.J.Curr.Microbiol.App.Sci. 9(06): 961-976. doi: https://doi.org/10.20546/ijcmas.2020.906.121 